\title{
REPORT
}

\section{Limited potential to recover from overfishing raises concerns for deep-sea sharks, rays and chimaeras}

\author{
COLIN A. SIMPFENDORFER ${ }^{1 *}$ AND PETER M. KYNE \\ ${ }^{1}$ School of Earth and Environmental Sciences, Fames Cook University, Tomnsville, Queensland 4811, Australia. ${ }^{2}$ School of Biomedical Sciences, \\ University of Queensland, St. Lucia, Queensland 4072, Australia, current address: Tropical Rivers and Coastal Knomledge, Charles Darmin \\ University, Darmin, Northern Territory 0909, Australia
}

Date submitted: 30 June 2009; Date accepted: 30 September 2009

\section{SUMMARY}

As global fishing effort increasingly expands into deeper water, concerns exist over the ability of deepsea fishes to sustain fisheries. There is however little quantitative evidence to support these concerns for the deep-sea cartilaginous fishes (Chondrichthyes: sharks, rays and chimaeras). This paper compiled available life history data for this group to analyse their ability to rebound from population declines relative to continental shelf and pelagic species. Deepsea cartilaginous fishes have rates of population increase that are on average less than half those of shelf and pelagic species, and include the lowest levels observed to date. Population doubling times indicate that once a stock has been depleted, it will take decades, and potentially centuries, before it will recover. Furthermore, population recovery rates decrease with increasing depth, suggesting species that occur deepest are those most vulnerable to fishing. These results provide the first assessment of the productivity of deep-sea chondrichthyans, highlighting that precautionary management of developing deepsea fisheries is essential if stocks and biodiversity are to be maintained.

Keymords: Chondrichthyes, elasmobranchs, intrinsic rebound potential, life history, population doubling time

\section{INTRODUCTION}

Increasing movement of fishing effort into the deep-sea (Morato et al. 2006), combined with a lag in the scientific study of these systems (Haedrich et al. 2001), has raised concerns over the sustainability of species occupying deepsea habitats (Roberts 2002). Substantial declines in stocks have already been documented for a range of deep-sea taxa (Graham et al. 2001; Devine et al. 2006). It is now well known that the slow growth, late maturation and longevity of bony fishes in the deep-sea limit their ability to sustain fisheries, making precautionary management important (Koslow et al. 2000; Cailliet et al. 2001). However, the ability of deep-sea

*Correspondence: Colin Simpfendorfer e-mail: colin.simpfendorfer @jcu.edu.au cartilaginous fishes (the Chondrichthyes: sharks, rays and chimaeras) to sustain fisheries and recover from overfishing is relatively unknown, owing to the paucity of life history data.

Like deep-sea bony fishes, the cartilaginous fishes are generally slow growing, late maturing and long-lived (Musick 1999). However, within the group there are a wide range of life histories along a continuum from very low productivity to relatively high productivity. For example, Australian sharpnose shark Rhizoprionodon taylori (Ogilby 1915) mature after only one year, live to seven years and have litters of up to 10 young every year after maturation (Simpfendorfer 1999). This species has a high intrinsic rate of population increase (the maximum rate at which a population could increase either to sustain fishing or recover from overfishing), and the population can double in size in a period of 2.55 years if it is substantially below carrying capacity (Simpfendorfer 1999). In contrast, spiny dogfish Squalus acanthias Linnaeus, 1758 in the Eastern North Pacific mature after 25 years, live to 70 years and have litters of approximately 22 young every three years after maturity (Jones \& Geen 1977; McFarlane \& Beamish 1987; Saunders \& McFarlane 1993). As a result, its intrinsic rate of increase is much lower, and it has a population doubling time of around 42 years (Smith et al. 1998). Most chondrichthyans studied to date fit on a continuum between these two species.

Work on the productivity of chondrichthyan species (i.e. their ability to sustain fishing pressure or recover from overfishing) has been largely restricted to those inhabiting the continental shelf or pelagic habitats (see Smith et al. 1998). There are few investigations of deep-sea species, largely due to the lack of appropriate life history data. However, recent research on the life history of deep-sea species has provided sufficient data to provide the first assessment of productivity trends for the group. We aimed to determine the intrinsic rebound potential and population doubling times of deep-sea chondrichthyan fishes, compare the results to those of shallowwater continental shelf and pelagic species and consider the implications of the results for management of the deep-sea.

\section{METHODS}

For our analysis we selected all deep-sea cartilaginous fishes (defined as those species whose distribution is predominantly at, are restricted to, or spend the majority of their life cycle 
Table 1 Species of deep-sea cartilaginous fishes for which adequate life history data were available to calculate productivity in this study, and the regions from which data were obtained.

\begin{tabular}{|c|c|c|}
\hline Family and scientific name & Common name & Region \\
\hline \multicolumn{3}{|l|}{ Squalidae (dogfish sharks) } \\
\hline Squalus blainvillei (Risso 1826) & Longnose spurdog & Mediterranean \\
\hline Squalus megalops (Macleay 1881) & Shortnose spurdog & Southern Africa \\
\hline Squalus mitsukurii Jordan \& Snyder, in Jordan \& Fowler 1903 & Shortspine spurdog & North-west Pacific \\
\hline \multicolumn{3}{|c|}{ Centrophoridae (gulper sharks) } \\
\hline Centrophorus granulosus (Bloch \& Schneider 1801) & Gulper shark & Mediterranean \\
\hline Centrophorus squamosus (Bonnaterre 1788) & Leafscale gulper shark & North-east Atlantic \\
\hline Deania calcea (Lowe 1839) & Birdbeak dogfish & North-east Atlantic and south-east Australia \\
\hline \multicolumn{3}{|l|}{ Etmopteridae (lantern sharks) } \\
\hline Etmopterus baxteri Garrick, 1957 & New Zealand lantern shark & South-east Australia \\
\hline \multicolumn{3}{|l|}{ Somniosidae (sleeper sharks) } \\
\hline Centroselachus crepidater (Bocage \& Capello 1864) & Longnose velvet dogfish & South-east Australia \\
\hline Proscymnodon plunketi (Waite 1909) & Plunket shark & South-east Australia \\
\hline \multicolumn{3}{|l|}{ Rajidae (hardnose skates) } \\
\hline Amblyraja radiata (Donovan 1808 ) & Thorny skate & North-west Atlantic \\
\hline Leucoraja naevus Müller \& Henle, 1841 & Cuckoo skate & North-east Atlantic \\
\hline Raja binoculata Girard, 1854 & Big skate & North-east Pacific \\
\hline \multicolumn{3}{|l|}{ Chimaeridae (shortnose chimaeras) } \\
\hline Chimaera monstrosa Linnaeus, 1758 & Rabbitfish & North-east Atlantic \\
\hline
\end{tabular}

at depths below $200 \mathrm{~m}$; for example species occurring on the continental and insular slopes and beyond, including abyssal plains and oceanic seamounts) that had sufficient reliable age and reproductive data to allow the calculation of productivity. In all, data were available for 15 stocks from 13 species, representing six chondrichthyan families (Table 1, Table 2). This represents a very small proportion $(2.5 \%)$ of the approximately 530 species of described deepsea cartilaginous fishes (Kyne \& Simpfendorfer 2009), but was sufficient to provide an indication of trends within the deep-sea environment.

The productivity of a species was determined using the intrinsic rebound potential method (Au \& Smith 1997; Smith et al. 1998). This method produces an estimate of population increase rates similar to the intrinsic rate of increase calculated in life tables $(r)$, but differs in having simpler data requirements and allowing for density-dependent compensation. Detailed information on the method, including assumptions, can be found in Smith et al. (1998). Data required to determine the intrinsic rebound potential $\left(r_{2 M}\right)$ were age at maturity $(\alpha)$, maximum reproductive age $(w)$, annual female litter size $(b$, total litter size divided by the proportion female and the periodicity of breeding), natural mortality $(M)$ and the proportion of the population surviving to maturity $\left(l_{\alpha}\right)$. We assumed maximum age to be the maximum observed age and a reproductive periodicity of two years for viviparous species. Natural mortality was estimated using the relationship with growth parameters (von Bertalanffy $k ; M=1.6 k$ ) (Jensen 1996). When $k$ was not available, an alternative method (Hoenig 1983) that calculated $M$ from maximum age $(M=1.44-0.982 \ln m)$ was used. The growth parameter approach was preferred, as most of the data was collected from populations that were being fished and to use the maximum age method it is necessary to assume that there is no fishing. The proportion of individuals reaching maturity was calculated using the function $l_{\alpha}=\mathrm{e}^{-\alpha \mathrm{M}}$. Annual egg production in skates is difficult to determine due to the continuous production of eggs over an extended season. This limited the number of species from this group for which data were available. Annual fecundity estimates were not available for chimaeras, so we used ovarian fecundity as a proxy for the reproductive output of rabbitfish Chimaera monstrosa Linnaeus, 1758.

The intrinsic rebound potential method assumes that maximum productivity of a population is reached when total mortality is equal to twice the level of natural mortality (i.e. $\left.r_{2 M}\right)$. However, for some shark species, it has been suggested that maximum productivity occurs at levels below twice natural mortality (Fowler 1988). For this reason we also calculated $r_{1.5 \mathrm{M}}$. We incorporated density-dependence by calculating $r_{2 M}$ assuming that reproductive output was increased by a factor of $25 \%$ (i.e. $1.25 b$ ). We compared intrinsic rebound potentials of deep-sea species to values for shelf and pelagic species from Smith et al. (1998).

\section{RESULTS}

The most conservative values of intrinsic rebound potential for deep-sea chondrichthyans $\left(r_{1.5 M} b\right)$ ranged from 0.0064 $\mathrm{yr}^{-1}$ for plunket shark Proscymnodon plunketi (Waite 1909) to $0.0371 \mathrm{yr}^{-1}$ for cuckoo skate Lencoraja naevus Müller \& Henle 1841; the most optimistic values $\left(r_{2 M} 1.25 b\right)$ ranged from $0.0187 \mathrm{yr}^{-1}$ for P. plunketi to $0.1100 \mathrm{yr}^{-1}$ for L. naevus (Table 3). Conservative values $\left(r_{1.5 \mathrm{M}} b\right)$ were mostly below 0.02 $\mathrm{yr}^{-1}$; optimistic values $\left(r_{2 M} 1.25 b\right)$ were mostly less than 0.05 $\mathrm{yr}^{-1}$. The intrinsic rebound potential of viviparous deep-sea 
Table 2 Life history data for deep-sea cartilaginous fishes used to calculate intrinsic rebound potential and population doubling time. Reprod per. $=$ reproductive periodicity $b=$ annual female litter size; $\alpha=$ age at maturity; $m=$ maximum reproductive age; $M=$ natural mortality; $l_{\alpha}=$ proportion of the population surviving to maturity. ${ }^{*}$ Calculated using the Hoenig (1983) method; ${ }^{1}$ Japan; ${ }^{2}$ Hancock Seamount; ${ }^{3}$ Pacific Ocean; ${ }^{4}$ Atlantic Ocean.

\begin{tabular}{|c|c|c|c|c|c|c|c|c|c|}
\hline Family and species & $\begin{array}{l}\text { Maximum } \\
\text { reported } \\
\text { depth }(m)\end{array}$ & $\begin{array}{l}\text { Litter } \\
\text { size }\end{array}$ & $\begin{array}{l}\text { Reprod } \\
\text { per. } \\
\text { (yrs) }\end{array}$ & $b$ & $A$ & $m$ & $M$ & $l_{a}$ & References \\
\hline \multicolumn{10}{|l|}{ Squalidae (dogfish sharks) } \\
\hline Squalus blainvillei & 440 & 4 & 2 & 1 & 5 & 8 & 0.1632 & 0.442 & $\begin{array}{l}\text { Cannizzaro et al. (1995); Sion et al. } \\
\text { (2003) }\end{array}$ \\
\hline Squalus megalops & 732 & 3 & 2 & 0.75 & 15 & 32 & 0.0480 & 0.487 & Watson \& Smale $(1998,1999)$ \\
\hline Squalus mitsukurii ${ }^{1}$ & 954 & 4.5 & 2 & 1.125 & 16 & 27 & 0.0816 & 0.271 & $\begin{array}{l}\text { Taniuchi et al. (1993); Taniuchi \& } \\
\text { Tachikawa (1999) }\end{array}$ \\
\hline Squalus mitsukurii ${ }^{2}$ & 954 & 3.5 & 2 & 0.875 & 15 & 27 & 0.0656 & 0.374 & Wilson \& Seki (1994) \\
\hline \multicolumn{10}{|c|}{ Centrophoridae (gulper sharks) } \\
\hline Centrophorus granulosus & 1440 & 1 & 2 & 0.25 & 16.5 & 39 & 0.1600 & 0.071 & $\begin{array}{l}\text { Guallart (1998); Guallart \& Vicent } \\
\text { (2001) }\end{array}$ \\
\hline Centrophorus squamosus & 2400 & 8.1 & 2 & 2.025 & 35 & 70 & $0.0651^{*}$ & 0.102 & Clarke et al. $(2001,2002 a)$ \\
\hline Deania calcea ${ }^{3}$ & 1470 & 8 & 2 & 2 & 21.5 & 37 & 0.0816 & 0.173 & Irvine (2004) \\
\hline Deania calcea ${ }^{4}$ & 1470 & 11 & 2 & 2.75 & 25 & 35 & 0.1232 & 0.046 & Clarke et al. $(2002 b)$ \\
\hline \multicolumn{10}{|l|}{ Etmopteridae (lantern sharks) } \\
\hline Etmopterus baxteri & 1500 & 9 & 2 & 2.25 & 30 & 57 & 0.0640 & 0.147 & Irvine (2004); Irvine et al. (2006a) \\
\hline \multicolumn{10}{|l|}{ Somniosidae (sleeper sharks) } \\
\hline Centroselachus crepidater & 2080 & 6 & 2 & 1.5 & 20 & 54 & 0.1152 & 0.100 & Irvine (2004); Irvine et al. (2006b) \\
\hline Proscymnodon plunketi & 1427 & 17 & 2 & 4.25 & 29 & 39 & $0.1156^{*}$ & 0.035 & Daley et al. (2002); Irvine (2004) \\
\hline \multicolumn{10}{|l|}{ Rajidae (hardnose skates) } \\
\hline Amblyraja radiate & 1400 & 15 & 1 & 7.5 & 11 & 16 & 0.1920 & 0.133 & $\begin{array}{l}\text { Berestovskii (1994); Sulikowski et al. } \\
\quad(2005,2006)\end{array}$ \\
\hline Leucoraja naevus & 500 & 90 & 1 & 45 & 4 & 8 & 0.3152 & 0.283 & $\begin{array}{l}\text { Du Buit (1976); Gallagher et al. } \\
\text { (2004) }\end{array}$ \\
\hline Raja binoculata & 800 & 1260 & 1 & 630 & 10 & 26 & 0.096 & 0.383 & $\begin{array}{l}\text { McFarlane \& King (2006); Ebert \& } \\
\text { Davis (2007) }\end{array}$ \\
\hline \multicolumn{10}{|c|}{ Chimaeridae (shortnose chimaeras) } \\
\hline Chimaera monstrosa & 1000 & 6.5 & 1 & 3.25 & 11 & 26 & 0.1600 & 0.172 & $\begin{array}{l}\text { Moura et al. (2004); Calis et al. } \\
\text { (2005) }\end{array}$ \\
\hline
\end{tabular}

Table 3 Intrinsic rebound potentials $\left(r_{1.5 M}, r_{2 M}\right)$ and population doubling times $(d t)$ of deep-sea cartilaginous fishes with no increase in reproductive output $(b)$ and with a $25 \%$ increase $(1.25 b) .{ }^{1}$ Atlantic Ocean; ${ }^{2}$ Hancock Seamount; ${ }^{3}$ Pacific Ocean; ${ }^{4}$ Japan

\begin{tabular}{|c|c|c|c|c|c|c|}
\hline Species & $r_{1.5 M} b\left(y r^{-1}\right)$ & $d t(y r s)$ & $r_{2 M} b\left(y r^{-1}\right)$ & $d t(y r s)$ & $r_{2 M} 1.25 b\left(y r^{-1}\right)$ & $d t$ (yrs) \\
\hline Proscymnodon plunketi & 0.0064 & 108.96 & 0.0119 & 58.35 & 0.0187 & 37.07 \\
\hline Centrophorus squamosus & 0.0070 & 99.53 & 0.0125 & 55.43 & 0.0175 & 39.66 \\
\hline Etmopterus baxteri & 0.0071 & 98.13 & 0.0130 & 53.50 & 0.0187 & 37.02 \\
\hline Squalus megalops & 0.0075 & 92.40 & 0.0144 & 48.07 & 0.0247 & 28.07 \\
\hline Deania calcea ${ }^{1}$ & 0.0076 & 91.66 & 0.0141 & 49.31 & 0.0218 & 31.73 \\
\hline Squalus mitsukurii ${ }^{2}$ & 0.0080 & 86.89 & 0.0153 & 45.30 & 0.0266 & 26.09 \\
\hline Deania calcea ${ }^{3}$ & 0.0083 & 83.79 & 0.0155 & 44.85 & 0.0237 & 29.25 \\
\hline Squalus mitsukurii ${ }^{4}$ & 0.0086 & 80.69 & 0.0163 & 42.40 & 0.0273 & 25.35 \\
\hline Centroselachus crepidater & 0.0133 & 52.15 & 0.0230 & 30.20 & 0.0314 & 22.05 \\
\hline Amblyraja radiata & 0.0149 & 46.39 & 0.0278 & 24.92 & 0.0457 & 15.18 \\
\hline Centrophorus granulosus & 0.0161 & 42.98 & 0.0278 & 24.96 & 0.0384 & 18.04 \\
\hline Squalus blainvillei & 0.0162 & 42.79 & 0.0312 & 22.23 & 0.0670 & 10.35 \\
\hline Raja binoculata & 0.0163 & 42.50 & 0.0302 & 22.94 & 0.0450 & 15.39 \\
\hline Chimaera monstrosa & 0.0202 & 34.35 & 0.0358 & 19.38 & 0.0508 & 13.63 \\
\hline Leucoraja naevus & 0.0371 & 18.69 & 0.0674 & 10.28 & 0.1100 & 6.30 \\
\hline
\end{tabular}


Figure 1 Intrinsic rebound potentials $\left(r_{2 M}\right)$ of deep-sea (solid circles) and shelf and pelagic (open circles) cartilaginous fishes as a function of age at maturity. Three letter abbreviations for location differentiate stocks of the same species $($ ATL $=$ Atlantic Ocean; HAN = Hancock Seamount; JAP = Japan; $\mathrm{PAC}=$ Pacific Ocean). Data for intrinsic rebound potential of shelf and pelagic species from Smith et al. (1998).

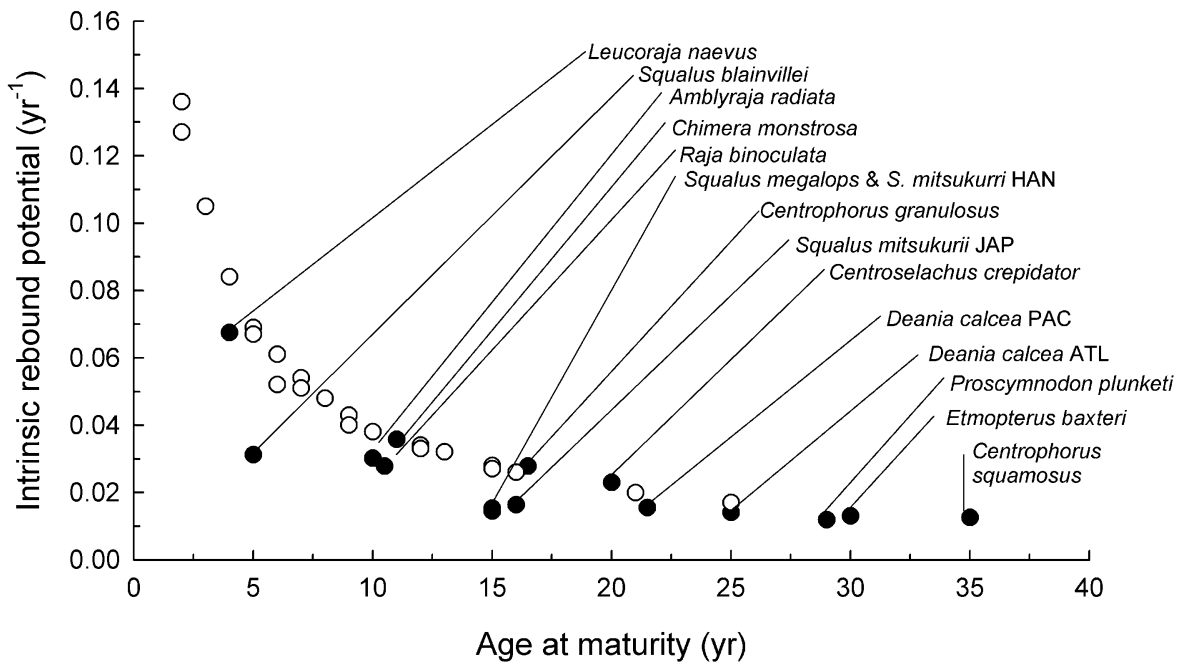

species (dogfish, gulper, lantern and sleeper sharks) (0.0153 $\mathrm{yr}^{-1}$ ) was significantly lower than that of oviparous species (skates and chimaeras) $\left(0.0330 \mathrm{yr}^{-1}\right)$ (Mann-Whitney rank sum test; $T=51.5 ; p=0.013)$.

Intrinsic rebound potentials for deep-sea species fell mostly at the lower end of the range exhibited by all cartilaginous fishes (Fig. 1) and, where overlap occurred, values were normally lower than for shallow-water species with the same age at maturity. The mean rebound potential of deep-sea species $\left(0.0233 \mathrm{yr}^{-1}\right)$ was significantly lower and less than half that of shelf and pelagic species $\left(0.0525 \mathrm{yr}^{-1}\right)(t$-test; $t=3.349$; $\mathrm{df}=38 ; p=0.002)$. These rates of increase $\left(r_{2 M} b\right.$ in Table 3) result in doubling times for depleted populations from 10 to 58 years, assuming no further fishing. Recovery from depletion is therefore very slow. More pessimistic scenarios based on evidence that maximum productivity of some shark populations occurs at lower levels of depletion than those presented in Figure 1 (Fowler 1988) produced even slower rebound potentials $\left(r_{1.5 M} b\right.$ in Table 3$)$ and doubling times of 19-109 years. Incorporating density-dependence and allowing for a $25 \%$ increase in reproductive output resulted in higher rates of increase $\left(r_{2 M} 1.25 b\right.$ in Table 3$)$ and more optimistic doubling times of $6-40$ years. All but a few of the intrinsic rebound potentials calculated, irrespective of whether they were conservative or optimistic, fell in the range considered to be very low (<0.05 $\mathrm{yr}^{-1}$; Musick et al. 2001). The few remaining values all fell within the low category $(0.05-0.15$ $\mathrm{yr}^{-1}$; Musick et al. 2001).

There was a significant decreasing trend in the intrinsic rebound potential with increasing reported maximum depth for the cartilaginous fishes as a whole $\left(r^{2}=0.305 ; F_{1,38}=\right.$ $16.69 ; p=0.0002$; Fig. 2).

\section{DISCUSSION}

Cartilaginous fishes display a range of life histories and hence productivities (Smith et al. 1998), but this study demonstrates that deep-sea chondrichthyans fall at the lower end of the productivity scale and include the lowest levels observed to date. Where the values for deep-sea species fell within the range of continental shelf and pelagic species they often had lower productivities for the same age at maturity. The values used in the comparison were moderate levels of rebound potential (i.e. $r_{2 M}$ ), and thus actual values may be even lower (i.e. $\left.r_{1.5 M}\right)$. These low levels of productivity are in part a function of the deep-sea environment, where low temperatures and limited food result in slow rates of growth and late maturity (Cailliet et al. 2001).

Shallow-water species show higher and more variable intrinsic rebound potentials than deep-sea species, which show lower and less variable values. This relationship suggests that the vast majority of deep-sea cartilaginous fishes occurring below $1000 \mathrm{~m}$ will have very low intrinsic rebound potentials, and thus limited abilities to sustain fishing or take long periods to recover from overfishing. Eight of the 15 deepsea species/stocks examined here had rates of increase $\left(r_{2 M}\right)$ resulting in population doubling times $>40$ years (as high as 58 years for $P$. plunketi). For shallow-water species, only a single species (the British Columbia population of $S$. acanthias) showed a population doubling time $>40$ years (all other species/stocks were $<30$ years) (Smith et al. 1998). Using conservative rates of increase $\left(r_{1.5 \mathrm{M}}\right)$, population doubling times were as great as 109 years (for $P$. plunketi). Added to the risk to deep-sea species is the observation that sharks do not occur below approximately $3000 \mathrm{~m}$ (Priede et al. 2006) and so, as a group, they do not have the extreme deepwater refuge from fisheries that the bony fishes do. The significant decline in the intrinsic rebound potential of species with increasing maximum depth provides the ability to predict, within the bounds of confidence intervals, the rebound potentials of species for which only the maximum depth of occurrence is known. This result is consistent with the observations of Dulvy and Reynolds (2002) that body size was the best indicator of extinction risk in skates and that body size (and hence extinction rate) increased with depth. 
Figure 2 Intrinsic rebound potentials $\left(r_{2 M}\right)$ of deep-sea (solid circles) and shelf and pelagic (open circles) cartilaginous fishes as a function of maximum depth of occurrence. Data for intrinsic rebound potential of shelf and pelagic species from Smith et al. (1998).

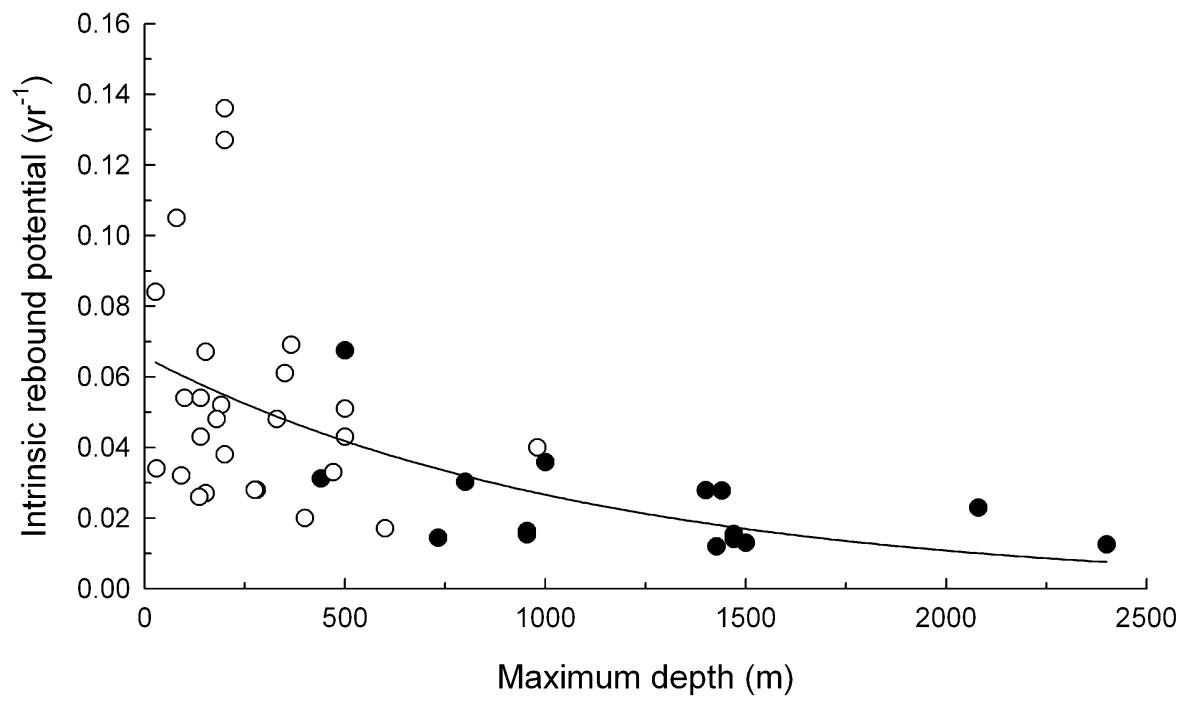

For the large majority of deep-sea sharks, rays and chimaeras, life history information is limited or completely lacking; the lack of available life history data limited the scope of this productivity assessment. A review of published literature as well as unpublished sources provided sufficient data to calculate productivity for only 13 species (15 stocks). Whole orders and families of deep-sea cartilaginous fishes were unrepresented in this analysis, which required reliable reproductive and age data. For the majority of sharks examined here (all dogfishes of the order Squaliformes), age data were derived from the analysis of dorsal spine bands (i.e. Clarke et al. 2002a, b; Irvine et al. 2006a, b), as opposed to traditional ageing methods that rely on seasonal changes in calcification rates of the vertebrae or caudal thorns to produce banding patterns. These techniques are of limited use for species from the stable and uniform habitats of the deep sea. Despite being one of the major groups of deepsea chondrichthyans, there are no age data available for the catsharks (family Scyliorhinidae), since their vertebral centra are unsuitable for ageing and they lack dorsal spines. Hence, this diverse and speciose shark family could not be included in this analysis, and will require the development of novel techniques in order to provide this important data.

The estimation of annual fecundities of egg-laying species (such as catsharks, skates, suborder Rajoidei, and chimaeras, order Chimaeriformes) is also problematic owing to the continuous production of eggs over an extended season. The number of skates (families Arhynchobatidae and Rajidae) examined here was limited by a lack of fecundity estimates, despite there being published age at maturity and maximum age data available for many species. The skates probably have the highest reproductive rates of any chondrichthyans, with some species potentially producing hundreds of eggs per year (annual fecundity has been estimated at 1260 for big skate Raja binoculata Girard, 1854, in which individual egg cases contain multiple eggs; Ebert \& Davis 2007). Despite these high reproductive outputs, many skates appear to be reproductively active for a relatively short period of their life (Ebert 2005).
This limitation on reproduction is likely to translate into low intrinsic rebound potentials as demonstrated by L. naevus, which despite having an annual fecundity of 90 (Du Buit 1976), had an intrinsic rebound potential of $0.0371 \mathrm{yr}^{-1}$ (under conservative estimates), owing to a short reproductive life of only six years (Ebert 2005). While this is the highest value amongst the deep-sea species examined, it still falls within the range of productivities considered to be very low $\left(<0.05 \mathrm{yr}^{-1}\right.$; Musick et al. 2001).

Using an approach calculating the fishing mortality necessary to drive chondrichthyans to extinction $\left(F_{\text {extinct }}\right)$, García et al. (2008) showed that extinction risk was highly associated with habitat; the average $F_{\text {extinct }}$ of deep-sea species was $58 \%$ of that required to drive continental shelf species to extinction. Interestingly, extinction risk was also associated with reproductive mode, being lower for oviparous species and higher in viviparous species (García et al. 2008). A similar pattern was determined for the rebound potential of deepsea chondrichthyans, with skates and chimaeras (oviparous species) having significantly higher $r_{2 M}$ values than the sharks (viviparous species) analysed here. The oviparous species incorporated into this analysis generally had larger litter sizes and/or lower ages at maturity than the viviparous species.

The simple demographic method used here required a number of assumptions about the populations analysed, including age-independent levels of natural and fishing mortality, no maternal size-litter size relationship and no fishing of juveniles (see Smith et al. 1998). The technique does however provide a standardized approach to obtaining productivity estimates, which allowed comparison between deep-sea taxa and amongst groups of chondrichthyan fishes (deep-sea versus continental shelf and pelagic species) (Smith et al. 1998). The ongoing collection of life history and fisheries data across the taxonomic range of deep-sea chondrichthyans is required to provide improved understanding of the risks facing this group.

The results of this study demonstrate that the chondrichthyan populations inhabiting the deep-sea are 
especially susceptible to overfishing because of the very low intrinsic rebound potentials. Assuming that the increasing movement of fisheries into the deep-sea (Morato et al. 2006) continues, deep-sea chondrichthyans are likely to come under increasing pressure. Given the low level of productivity of these populations it is likely that any fisheries targeting them, or taking them as a significant bycatch, will quickly deplete stocks. Sustained intensive deep-sea fishing could potentially lead to species extinctions (García et al. 2008), a loss of biodiversity and ecosystem level changes as a result of the loss of high trophic level predators. There are few data on the effects of fishing on deep-sea chondrichthyans, but those studies available typically show substantial declines (i.e. Graham et al. 2001). As fisheries move into deeper waters, the effects on chondrichthyans will increase, with those that live deeper more vulnerable. Policy makers and resource managers responsible for the deep sea must therefore take a precautionary approach considering the consequences of deep-sea fisheries, not only because of the inability of deepsea sharks, rays and chimaeras to sustain fishing, but also the very long recovery times that are required from even short periods of fishing.

\section{ACKNOWLEDGEMENTS}

The Marine Conservation Biology Institute provided funding. We thank Lance Morgan for project assistance, Sarah Irvine for access to life history data, and Claire Bartron, Michelle Heupel and Chris Glen for comments on the manuscript.

\section{References}

Au, D.W. \& Smith, S.E. (1997) A demographic method with population density compensation for estimating productivity and yield per recruit of the leopard shark (Triakis semifasciata). Canadian Fournal of Fisheries and Aquatic Sciences 54: 415-420.

Berestovskii, E.G. (1994) Reproductive biology of skates of the family Rajidae in the seas of the far north. Fournal of Ichthyology 34: 2637.

Cailliet, G.M., Andrews, A.H., Burton, E.J., Watters, D.L., Kline, D.E. \& Ferry-Graham, L.A. (2001) Age determination and validation studies of marine fishes: do deep-dwellers live longer? Experimental Gerontology 36: 739-764.

Calis, E., Jackson, E.H., Nolan, C.P. \& Jeal, F. (2005) Preliminary age and growth estimates of the rabbitfish, Chimaera monstrosa, with implications for future resource management. Fournal of Northwest Atlantic Fishery Science 35: 15-26.

Cannizzaro, L., Rizzo, P., Levi, D. \& Gancitano, S. (1995) Age determination and growth of Squalus blainvillei (Risso, 1826). Fisheries Research 23: 113-125.

Clarke, M.W., Connolly, P.L. \& Bracken, J.J. (2001) Aspects of reproduction of the deep water sharks Centroscymnus coelolepis and Centrophorus squamosus from west of Ireland and Scotland. Fournal of the Marine Biological Association of the United Kingdom 81: 1019-1029.

Clarke, M.W., Connolly, P.L. \& Bracken, J.J. (2002a) Age estimation of the exploited deepwater shark Centrophorus squamosus from the continental slopes of the Rockall Trough and Porcupine Bank. Fournal of Fish Biology 60: 501-514.

Clarke, M.W., Connolly, P.L. \& Bracken, J.J. (2002b) Catch, discarding, age estimation, growth and maturity of the squalid shark Deania calceus west and north of Ireland. Fisheries Research 56: $139-153$.

Daley, R., Stevens, J. \& Graham, K. (2002) Catch analysis and productivity of the deepwater dogfish resource in Southern Australia. Fisheries Research and Development Corporation Final Report, 1998/108. Canberra, Australia.

Devine, J.A., Baker, K.D. \& Haedrich, R.L. (2006) Deep-sea fishes qualify as endangered. Nature 439: 29.

Du Buit, M.H. (1976) The ovarian cycle of the cuckoo ray, Raja naevus (Müller and Henle), in the Celtic Sea. Fournal of Fish Biology 8: 199-207.

Dulvy, N.K. \& Reynolds, J.D. (2002) Predicting extinction vulnerability in skates. Conservation Biology 16: 440-450.

Ebert, D.A. (2005) Reproductive biology of skates, Bathyraja (Ishiyama), along the eastern Bering Sea continental slope. Fournal of Fish Biology 66: 618-649.

Ebert, D.A. \& Davis, C.D. (2007) Descriptions of skate egg cases (Chondrichthyes: Rajiformes: Rajoidei) from the eastern North Pacific. Zootaxa 1393: 1-18.

Fowler, C.W. (1988) Population dynamics as related to rate of increase per generation. Evolutionary Ecology 2: 197-204.

Gallagher, M.J., Nolan, C.P. \& Jeal, F. (2004) Age, growth and maturity of the commercial ray species from the Irish Sea. Fournal of Northwest Atlantic Fishery Science 35: 47-66.

García, V.B., Lucifora, L.O. \& Myers, R.A. (2008) The importance of habitat and life history to extinction risk in sharks, skates, rays and chimaeras. Proceedings of the Royal Society, B 275: 8389.

Graham, K.J., Andrew, N.L. \& Hodgson, K.E. (2001) Changes in relative abundance of sharks and rays on Australian South East Fishery trawl grounds after twenty years of fishing. Marine and Freshwater Research 52: 549-561.

Guallart, J. (1998) Contribución al conocimientto de la taxonomía y la biología del tiburón batial Centrophorus granulosus (Bloch \& Schneider, 1801) (Elasmobranchii, Squalidae) en el Mar Balear (Mediterráneo occidental). PhD Thesis, Universitat de Valencia, Spain.

Guallart, J. \& Vicent, J.J. (2001) Changes in composition during embryo development of the gulper shark, Centrophorus granulosus (Elasmobranchii, Centrophoridae): an assessment of maternalembryonic nutritional relationships. Environmental Biology of Fishes 61: 135-150.

Haedrich, R.L., Merrett, N.R. \& O'Dea, N.R. (2001) Can ecological knowledge catch up with deep-water fishing? A North Atlantic perspective. Fisheries Research 51: 113-122.

Hoenig, J.M. (1983) Empirical use of longevity data to estimate mortality rates. Fishery Bulletin 82: 898-903.

Irvine, S.B. (2004) Age, growth and reproduction of deepwater dogfishes from southeastern Australia. PhD Thesis, Deakin University, Australia.

Irvine, S.B., Stevens, J.D. \& Laurenson, L.J.B. (2006a) Comparing external and internal dorsal-spine bands to interpret the age and growth of the giant lantern shark, Etmopterus baxteri (Squaliformes: Etmopteridae). Environmental Biology of Fishes 77: 253-264.

Irvine, S.B., Stevens, J.D. \& Laurenson, L.J.B. (2006b) Surface bands on deepwater squalid dorsal-fin spines: an alternative 
method for ageing Centroselachus crepidater. Canadian fournal of Fisheries and Aquatic Sciences 63: 617-627.

Jensen, A.L. (1996) Beverton and Holt life history invariants result from optimal trade-off of reproduction and survival. Canadian Fournal of Fisheries and Aquatic Sciences 53: 820-822.

Jones, B.C. \& Geen, G.H. (1977) Reproduction and embryonic development of spiny dogfish (Squalus acanthias) in the Strait of Georgia, British Columbia. Fournal of the Fisheries Research Board of Canada 34: 1286-1292.

Koslow, J.A., Boehlert, G.W., Gordon, J.D.M., Haedrich, R.L., Lorance, P. \& Parin, N. (2000) Continental slope and deep-sea fisheries: implications for a fragile ecosystem. ICES fournal of Marine Science 57: 548-557.

Kyne, P.M. \& Simpfendorfer, C.A. (2009) Deepwater chondrichthyans. In: Biology of Sharks and Their Relatives. Volume 2, ed. J.C. Carrier, J.A. Musick \& M.R. Heithaus (in press). Boca Raton, USA: CRC Press.

McFarlane, G.A. \& Beamish, R.J. (1987) Validation of the dorsal spine method of age determination for spiny dogfish. In: Age and Gromth of Fish, ed. R.C. Summerfelt \& G.E. Hall, pp. 287-300. Ames, USA: The Iowa State University Press.

McFarlane, G.A. \& King, J.R. (2006) Age and growth of big skate (Raja binoculata) and longnose skate (Raja rhina) in British Columbia waters. Fisheries Research 78: 169-178.

Morato, T., Watson, R., Pitcher, T.J. \& Pauly, D. (2006) Fishing down the deep. Fish and Fisheries 7: 24-34.

Moura, T., Figueiredo, I., Bordalo Machado, P. \& Serrano Gordo, L. (2004) Growth pattern and reproductive strategy of the holocephalan Chimaera monstrosa along the Portuguese continental slope. Fournal of the Marine Biological Association of the United Kingdom 84: 801-804.

Musick, J.A. (1999) Ecology and conservation of long-lived marine animals. In: Life in the Slow Lane: Ecology and Conservation of Long-lived Marine Animals, ed. J.A. Musick, pp. 1-10. Bethesda, USA: American Fisheries Society Symposium 23.

Musick, J.A., Harbin, M.M., Berkeley, S.A., Burgess, G.H., Eklund, A.M., Findley, L., Gilmore, R.G., Golden, J.T., Ha, D.S., Huntsman, G.R., McGovern, J.C., Parker, S.J., Poss, S.G., Sala, E., Schmidt, T.W., Sedberry, G.R., Weeks, H. \& Wright, S.G. (2001) Marine, estuarine, and diadromous fish stocks at risk of extinction in North America (exclusive of Pacific salmonids). Fisheries 25: 6-30.

Priede, I.G., Froese, R., Bailey, D.M., Aksel Bergstad, O., Collins, M.A., Erik Dyb, J., Henriques, C., Jones, E.G. \& King, N. (2006) The absence of sharks from the abyssal regions of the world's oceans. Proceedings of the Royal Society, B 273: 14351441.

Roberts, C.M. (2002) Deep impact: the rising toll of fishing in the deep sea. Trends in Ecology and Evolution, 17: 242-245.

Saunders, M.W. \& McFarlane, G.A. (1993) Age and length at maturity of the spiny dogfish, Squalus acanthias, in the Strait of Georgia, British Columbia, Canada. Environmental Biology of Fishes 38: 49-57.

Simpfendorfer, C.A. (1999) Mortality estimates, and demographic analysis for the Australian sharpnose shark, Rhizoprionodon taylori, from northern Australia. Fishery Bulletin 97: 978-986.

Sion, L., D’Onghia, G., Tursi, A. \& Mytilineou, Ch. (2003) First data on distribution and biology of Squalus blainvillei (Risso, 1826) from the eastern Mediterranean Sea. Fournal of Northmest Atlantic Fishery Science 31: 213-219.

Smith, S.E., Au, D.W. \& Show, C. (1998) Intrinsic rebound potentials of 26 species of Pacific sharks. Marine and Freshmater Research 49: 663-678.

Sulikowski, J.A., Kneebone, J., Elzey, S., Jurek, J., Danley, P.D., Howell, W.H. \& Tsang, P.C.W. (2005) Age and growth estimates of the thorny skate (Amblyraja radiata) in the western Gulf of Maine. Fishery Bulletin 103: 161-168.

Sulikowski, J.A., Kneebone, J., Elzey, S., Jurek, J., Howell, W.H. \& Tsang, P.C.W. (2006) Using the composite variables of reproductive morphology, histology and steroid hormones to determine age and size at sexual maturity for the thorny skate Amblyraja radiata in the western Gulf of Maine. Fournal of Fish Biology 69: 1449-1465.

Taniuchi, T. \& Tachikawa, H. (1999) Geographical variation in age and growth of Squalus mitsukurii (Elasmobranchii: Squalidae) in the North Pacific. In: Proceedings 5th Indo-Pacific Fish Conference, Noumea, New Caledonia, 3-8 November 1997, ed. B. Séret \& J.-Y. Sire, pp. 321-328. Paris, France: Société Française d'Ichthyologie.

Taniuchi, T., Tachikawa, H., Shimizu, M. \& Nose, Y. (1993) Geographical variations in reproductive parameters of shortspine spurdog in the North Pacific. Nippon Suisan Gakkaishi 59: 45-51.

Watson, G. \& Smale, M.J. (1998) Reproductive biology of shortnose spiny dogfish, Squalus megalops, from the Agulhas Bank, South Africa. Marine and Freshmater Research 49: 695-703.

Watson, G. \& Smale, M.J. (1999) Age and growth of the shortnose spiny dogfish Squalus megalops from the Agulhas Bank, South Africa. South African fournal of Marine Science 21: 9-18.

Wilson, C.D. \& Seki, M.P. (1994) Biology and population characteristics of Squalus mitsukurii from a seamount in the central North Pacific Ocean. Fishery Bulletin 92: 851-864. 